\title{
SISTEM INFORMASI BUKU INDUK SISWA
}

\author{
Luh Putu Cintya Prabandari \\ Manajemen Informatika, Politeknik Ganesha Guru \\ Email: cintyaprabandari@gmail.com
}

\begin{abstract}
ABSTRAK
Gempa, banjir, tanah longsor, kebakaran merupakan kejadian yang tidak terduga dan tidak dapat diprediksi terutama kejadian alam. Seringkali kejadian tersebut membawa dampak yang tidak terduga seperti kehilangan harta benda, sanak saudara dan dokumen-dokumen penting. Pada penelitian ini lebih menekankan pada pemecahan permasalahan kehilangan dokumen-dokumen penting seperti ijasah SMA. Sistem Informasi Buku Induk Siswa yang diharapkan dapat membantu data menjadi terkomputerisasi yang dapat diakses secara online. Di dalam sistem ini, terdapat pengolahan data yang pada awalnya data berasal dari sumber tertulis kemudian menjadi data yang terkomputerisasi sehingga memudahkan dalam penyimpanan dan pencarian data. Dengan adanya sistem ini, membantu dalam pencarian data siswa yang masih aktif atau tercatat sebagai siswa dan pencarian data alumni siswa. Pengujian yang telah dilakukan menunjukkan hasil yang baik ditunjukkan dengan semua fungsional form berjalan sesuai dengan kebutuhan fungsional yang telah dirancang sebelumnya.
\end{abstract}

Kata kunci: sibuki, sistem, buku, induk

\begin{abstract}
Abstrak Earthquakes, floods, landslides, fires are unexpected and unpredictable events, especially natural events. Often these events have unexpected effects such as loss of property, relatives and important documents. In this study, the emphasis was on solving the problem of losing important documents such as a high school diploma. Student Master Book Information System which is expected to help data become computerized which can be accessed online. In this system, there is data processing that initially data originates from written sources and then becomes computerized data making it easier for data storage and searching. With this system, it helps in finding data on students who are still active or recorded as students and search for student alumni data. Tests that have been carried out show good results indicated by all functional forms running in accordance with functional requirements that have been previously designed
\end{abstract}

Keywords : sibuki, system, master, book

\section{PENDAHULUAN}

Pesatnya kemajuan peradaban manusia salah satunya disebabkan dengan adanya temuan-temuan di bidang teknologi informasi dan komunikasi. Tidak berlebihan jika abad ini lebih dikenal sebagai abad informasi. Hal ini dikarenakan perkembangan teknologi informasi begitu pesat dan merambah ke berbagai bidang kehidupan. Teknologi informasi yang secara sederhana disimbolkan dengan perangkat komputer dan jaringan internet serta teknologi komunikasi. Dan teknologi informasi telah banyak dimanfaatkan untuk meningkatkan produktivitas manusia. Seiring teknologi yang berkembang, penerapan teknologi informasi atau teknologi komputer sangat diperlukan untuk mendukung pengembangan media informasi[1]. Untuk itu dikembangkan Sistem Informasi Buku Induk Siswa yang diharapkan dapat membantu data menjadi terkomputerisasi yang dapat diakses secara online. Di dalam sistem ini, terdapat pengolahan data yang pada awalnya data berasal dari sumber tertulis kemudian menjadi data yang terkomputerisasi sehingga 
memudahkan dalam penyimpanan dan pencarian data. Dengan adanya sistem ini, membantu dalam pencarian data siswa yang masih aktif atau tercatat sebagai siswa dan pencarian data alumni siswa.

Menurut Sutono, sistem informasi dalam suatu pemahaman yang sederhana dapat didefinisikan sebagai satu sistem berbasis komputer yang menyediakan informasi bagi beberapa pemakai dengan kebutuhan yang serupa. Para pemakai biasanya tergabung dalam suatu entitas organisasi formal, seperti Departemen atau Lembaga suatu Instansi Pemerintahan yang dapat dijabarkan menjadi Direktorat, Bidang, Bagian sampai pada unit terkecil dibawahnya. Informasi menjelaskan mengenai organisasi atau salah satu sistem utamanya mengenai apa yang telah terjadi di masa lalu, apa yang sedang terjadi sekarang dan apa yang mungkin terjadi dimasa yang datang tentang organisasi tersebut Sistem informasi memuat berbagai informasi penting mengenai orang, tempat, dan segala sesuatu yang ada di dalam atau di lingkungan sekitar organisasi. Informasi sendiri mengandung suatu arti yaitu data yang telah diolah ke dalam suatu bentuk yang lebih memiliki arti dan dapat digunakan untuk pengambilan keputusan. Data sendiri merupakan fakta-fakta yang mewakili suatu keadaan, kondisi, atau peristiwa yang terjadi atau ada di dalam atau di lingkungan fisik organisasi. Data tidak dapat langsung digunakan untuk pengambilan keputusan, melainkan harus diolah lebih dahulu agar dapat dipahami, lalu dimanfaatkan dalam pengambilan keputusan. Informasi harus dikelola dengan baik dan memadai agar memberikan manfaat yang maksimal. Penerapan sistem informasi di dalam suatu organisasi dimaksudkan untuk memberikan dukungan informasi yang dibutuhkan, khususnya oleh para pengguna informasi dari berbagai tingkatan manajemen [2].

Dewasa ini, sistem informasi yang digunakan lebih berfokus pada sistem informasi berbasis komputer (computer-based information system). Harapan yang ingin diperoleh di sini adalah bahwa dengan penggunaan teknologi informasi atau sistem informasi berbasis komputer, informasi yang dihasilkan dapat lebih akurat, berkualitas, dan tepat waktu, sehingga pengambilan keputusan dapat lebih efektif dan efisien[3]. Dalam penelitian ini dikembangkan sistem informasi buku induk siswa.

Buku induk siswa adalah buku berukuran besar yang digunakan untuk mencatat semua data siswa sejak awal berdirinya sebuah lembaga pendidikan. Dahulu cara pengisian buku induk siswa masih dilakukan secara manual yaitu dengan menuliskan data siswa pada buku. Bahkan sampai sekarang banyak lembaga pendidikan yang masih menggunakan cara manual tersebut untuk melakukan pengisian buku induk siswa. Buku induk siswa berasal dari gabungan dua kata utama yaitu buku induk dan siswa. Menurut KBBI, buku induk adalah buku yang memuat daftar nama beserta jati diri orang yang tercatat sebagai anggota suatu organisasi, murid sekolah, warga suatu wilayah. Sedangkan pengertian siswa menurut Undang-Undang Nomor 20 Tahun 2003 tentang Sistem Pendidikan Nasional adalah anggota masyarakat yang berusaha mengembangkan potensi diri melalui proses pembelajaran yang tersedia pada jalur, jenjang, dan jenis pendidikan tertentu

Berdasarkan uraian di atas, akan sangat sulit jika cara pengisian buku induk masih dilakukan secara manual karena cara tersebut memiliki beberapa kelemahan antara lain pengisian data siswa membutuhkan banyak waktu dan tenaga, buku mudah rusak apabila disimpan terlalu lama, membutuhkan tempat penyimpanan yang khusus, dan membutuhkan waktu yang cukup lama untuk mencari dan mencocokkan data. Buku induk siswa merupakan daftar nama siswa yang belajar di sekolah tersebut. Catatan di dalam buku induk harus lengkap meliputi, biodata siswa dan hasil prestasi belajar siswa dari semester pertama hingga lulus. Biodata siswa tersebut terdiri dari nama, nis, tempat/tanggal lahir, nama orang tua/wali murid, alamat, pekerjaan, dan sebagainya. 


\section{PERANCANGAN SISTEM}

Sistem Informasi Buku Induk Siswa memiliki manfaat seperti memudahkan pencarian data bagi siswa yang masih aktif dan alumni yang telah berubah statusnya menjadi alumni, mempermudah memasukkan data siswa yang berjumlah banyak dan mencetak buku induk siswa dimana arsip dapat berupa data file yang dapat diakses komputer. Dengan manfaat yang didapatkan, akan meminimalkan pengarsipan berkas-berkas buku induk siswa menjadi berkas-berkas file yang disimpan didalam komputer. Proses Sistem Informasi Buku Induk Siswa dapat digambarkan dengan diagram alir buku induk.

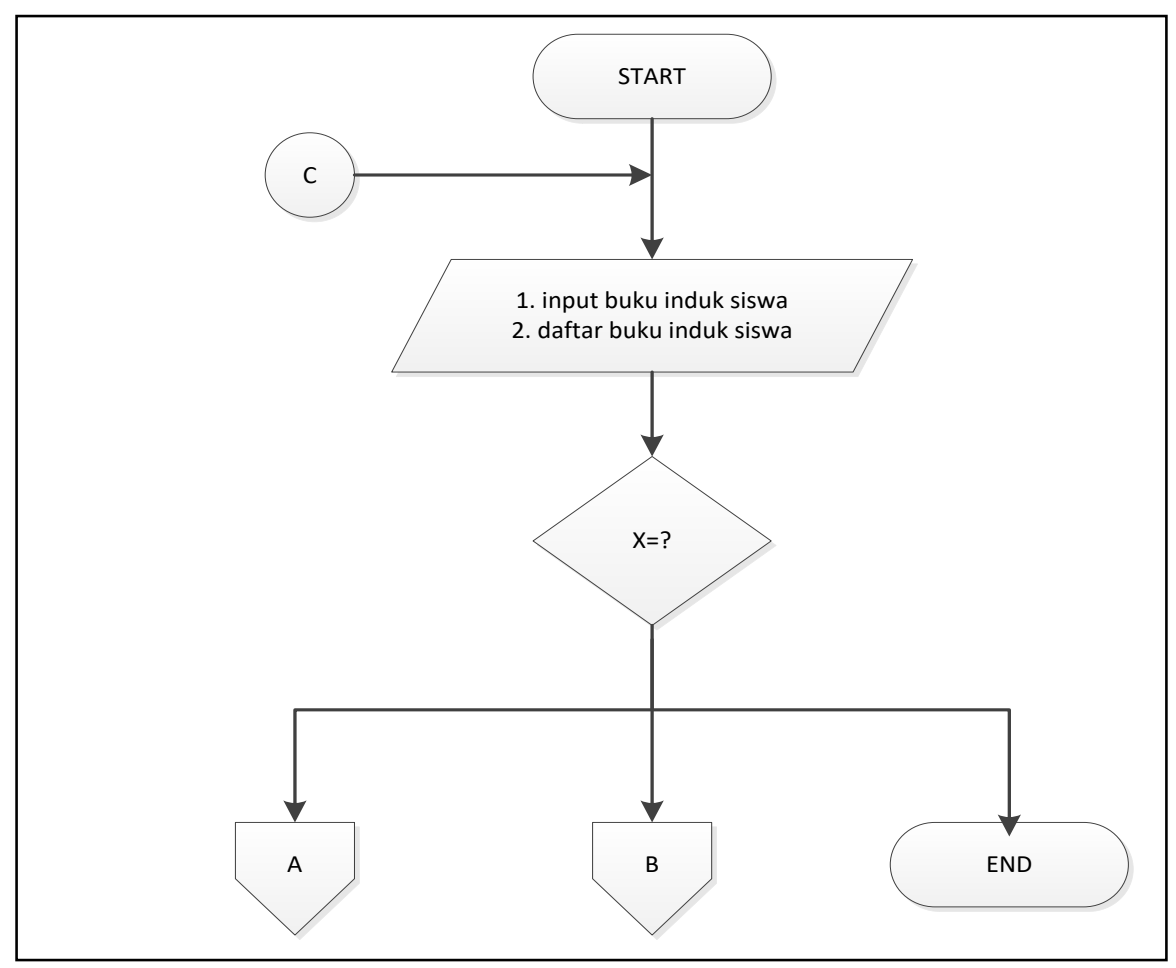

Gambar 1. Diagram Alir Buku Induk

Gambar 1 merupakan diagram alir dari perancangan sistem informasi buku induk siswa. Pengguna akan masuk ke halaman utama proses buku induk siswa. Pengguna dalam sistem ini adalah administrator. Sebelum masuk ke sistem, pengguna terlebih dahulu login ke dalam sistem dengan username dan password yang telah disimpan dalam database. Pada sistem ini pengguna dapat memasukkan data buku induk siswa, menampilkan data buku induk siswa dan mencetak data buku induk siswa. Selain itu, pengguna dapat mencari data yang diinginkan untuk dapat diambil tindakan apakah untuk memperbaiki data atau mencetak data. Pengguna memasukkan data pada menu input buku induk siswa dan melakukan proses pencarian. Menu daftar buku induk siswa menunjukkan daftar data siswa. Proses masukan data dapat dilihat pada gambar 2 diagram alir proses masukan nilai. Dan proses menampilkan dan mencetak data siswa, skema prosesnya dapat dilihat pada gambar 3 diagram alir proses daftar buku induk siswa. 


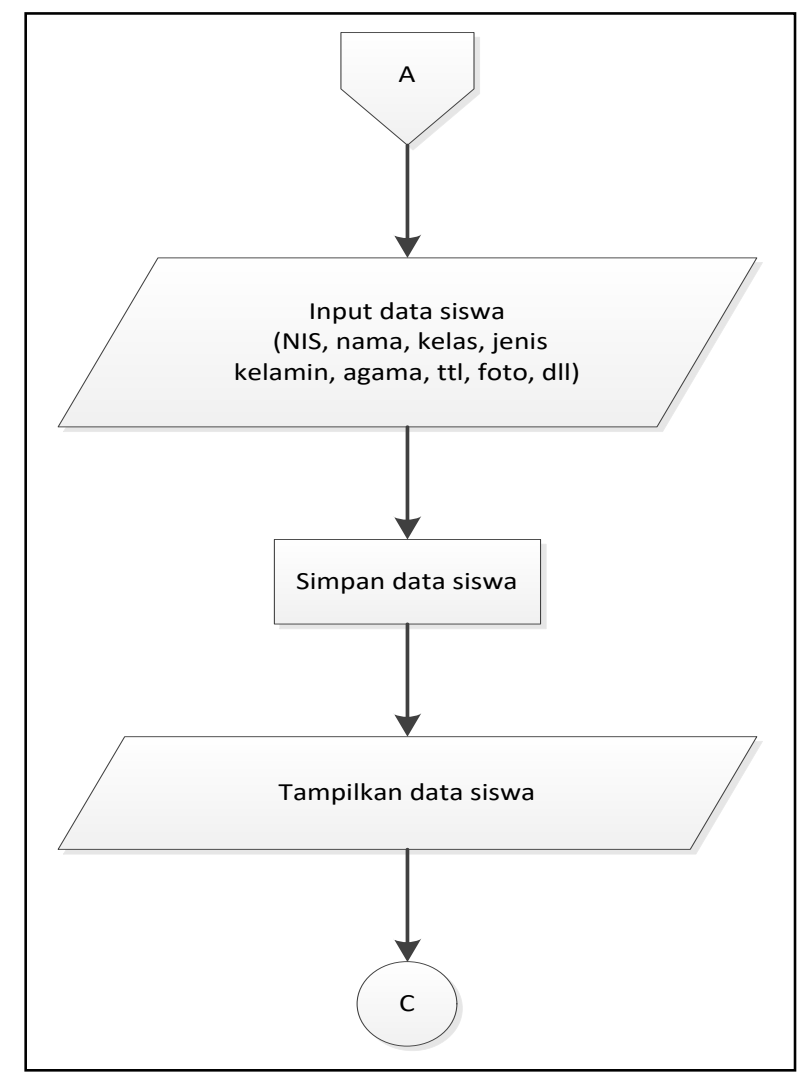

Gambar 2. Diagram alir proses masukan nilai

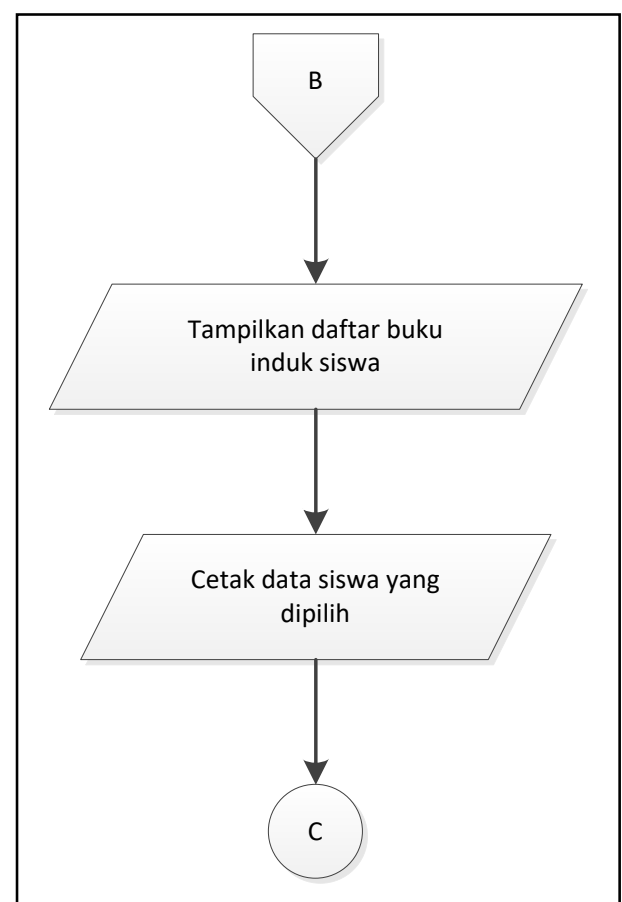

Gambar 3. Diagram Alir Proses Daftar Buku Induk Siswa 


\section{HASIL DAN PEMBAHASAN}

Berdasarkan rancangan yang telah dibuat berikut adalah hasil implementasi perangkat lunaknya yaitu antarmuka tampilan halaman beranda, antarmuka tampilan halaman login, antarmuka tampilan halaman administrator, antarmuka tampilan halaman pencarian data, antarmuka tampilan halaman input data siswa, antarmuka tampilan halaman daftar data siswa dan antarmuka tampilan halaman cetak buku induk siswa. Selain untuk mengatur buku induk siswa, pengguna juga dapat mengatur menu dan pengguna lainnya. Fitur pengaturan ini berguna agar administrator dapat menambah menu tambahan pada sistem jika ada pengembangan lebih lanjut. Fitur pengaturan pengguna ini memudahkan administrator untuk mengatur pengguna yang dapat menggunakan sistem.

a. Hasil Antarmuka Tampilan Halaman Beranda

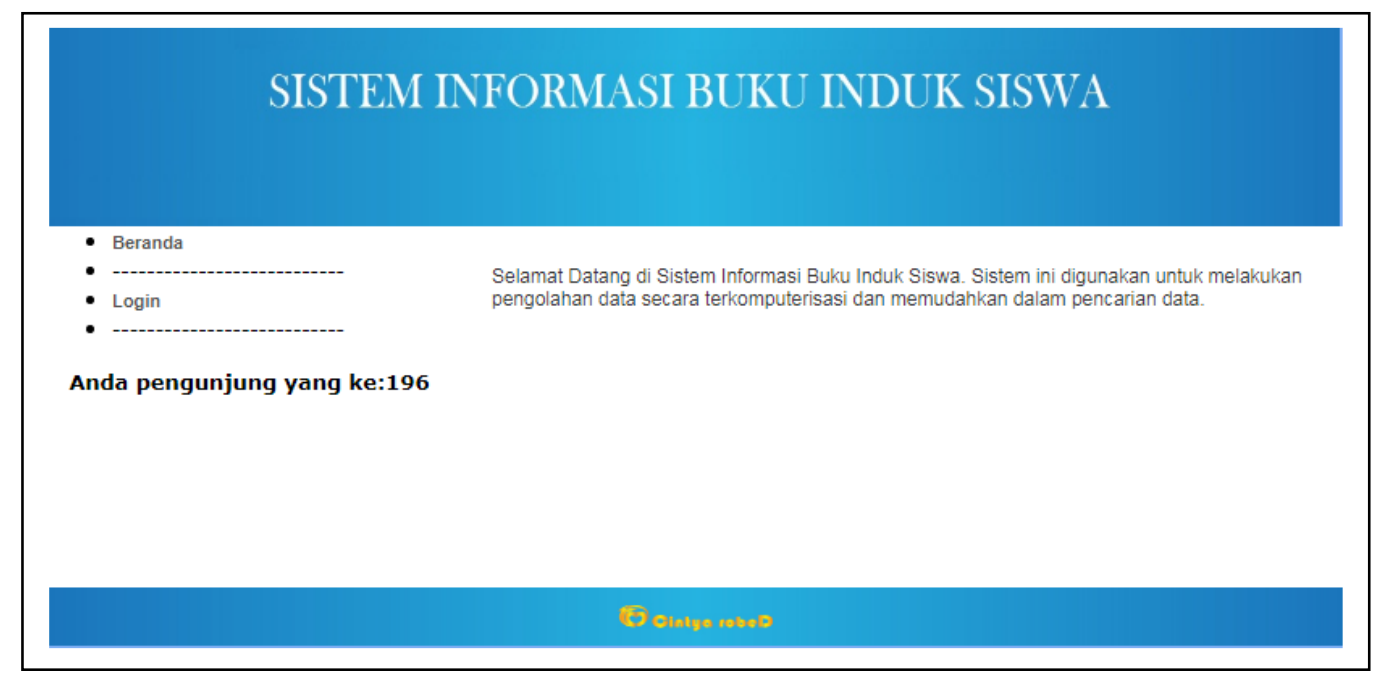

Gambar 4. Hasil Antarmuka Tampilan Beranda

Gambar 4 merupakan antarmuka tampilan beranda sistem informasi buku induk siswa. Halaman ini berisikan menu beranda dan login di sisi kiri pengguna dengan mencantumkan jumlah pengunjung sistem di bagian bawah menu. Pada sisi kanan sistem berisikan deskripsi tentang sistem informasi buku induk siswa. Jika memilih menu beranda maka pengguna dihubungkan ke menu utama seperti saat membuka alamat website pertama kali. Dan menu login digunakan pengguna untuk masuk ke halaman administrator seperti yang terlihat pada gambar 5 .

Halaman login diperuntukkan untuk pengguna, yang dimaksudkan adalah administrator. Administrator dapat masuk ke dalam halaman utama administrator dengan memasukkan username dan password yang tepat. Jika username dan password yang dimasukkan sesuai dengan yang disimpan saat pengaturan pengguna maka administrator dapat mengakses halaman administrator. Jika salah memasukkan usernama atau password maka administrator diingatkan bahwa username atau password yang dimasukkan salah. Pada bagian bawah terdapat link "home" yang digunakan pengguna untuk kembali ke halaman beranda. 
b. Hasil Antarmuka Tampilan Halaman Login

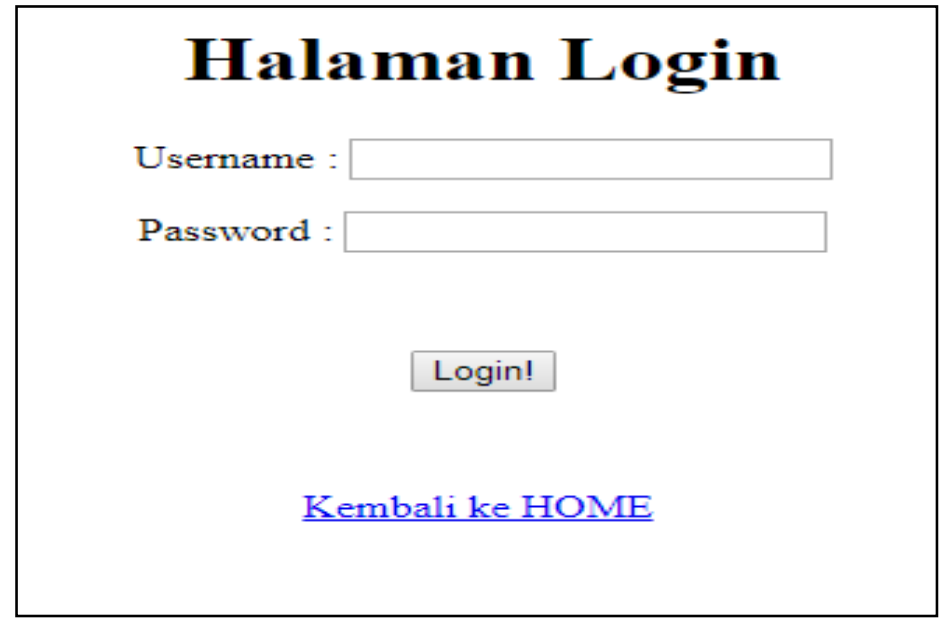

Gambar 5. Hasil Antarmuka Tampilan Login

c. Hasil Antarmuka Tampilan Halaman Administrator

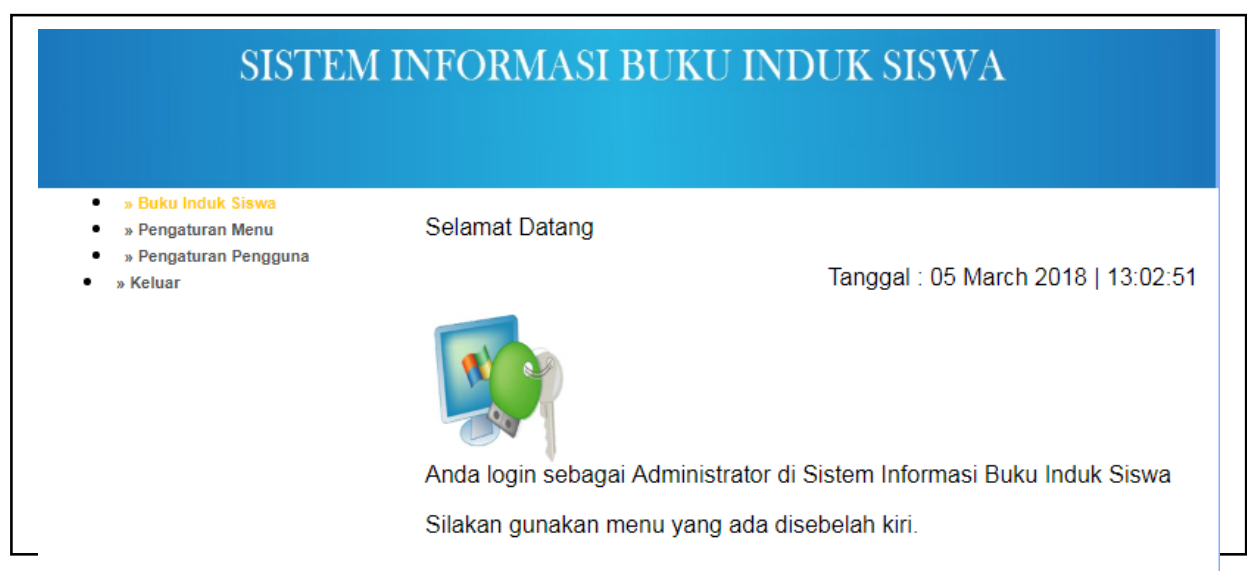

d. $\mathrm{Ha}$

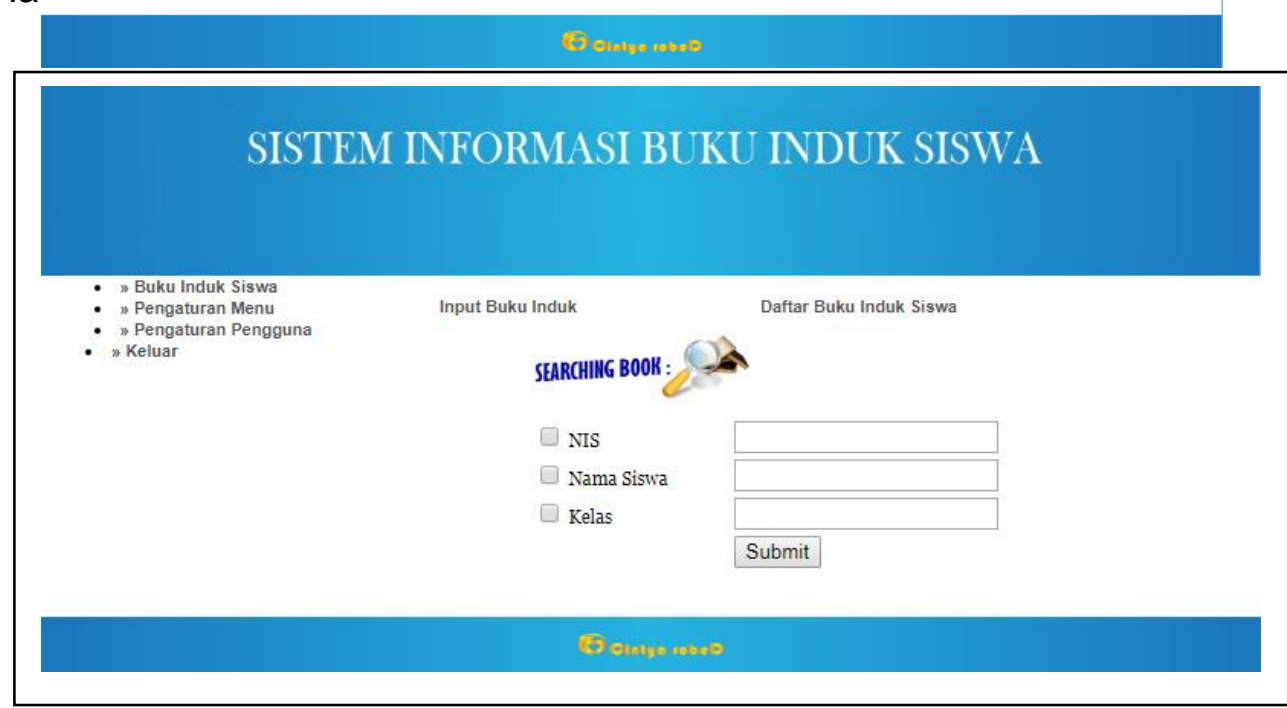

Gambar 7. Hasil Antarmuka Tampilan Halaman Pencarian Data 
e. Hasil Antarmuka Tampilan Halaman Input Data Siswa

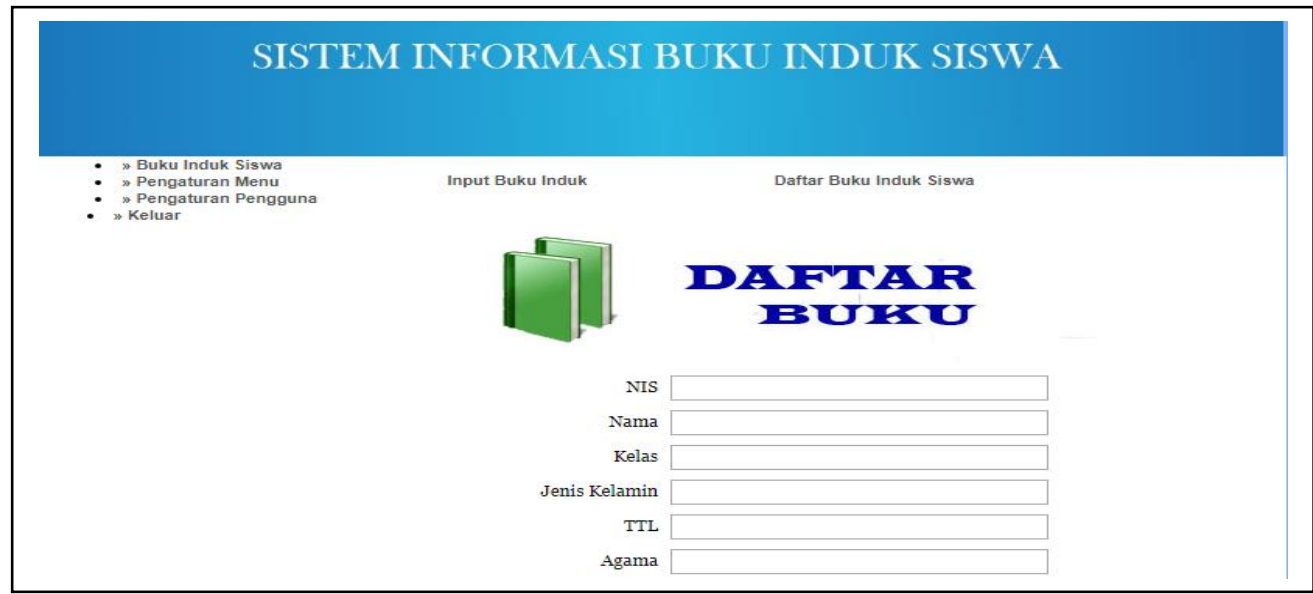

Gambar 8. Hasil Antarmuka Tampilan Halaman Input Data Siswa

Berikut ini tampilan form

Hasil antar muka data siswa yang berfungsi untuk melakukan perubahan data siswa yang meliputi semua data siswa yang telah terdaftar kecuali NIS. Langkah yang harus kita lakukan untuk melakukan edit data siswa pertama kali adalah klik menu Cari dan Edit kemudian klik NIS lalu masukkan NIS pada kotak yang telah disediakan. Setelah itu, klik tombol Cari maka akan muncul data siswa yang kita cari kemudian klik tombol Edit maka akan muncul form seperti dibawah ini. Setelah melakukan perubahan data klik tombol Perbarui untuk menyimpan data siswa.

f. Hasil Antarmuka Tampilan Halaman Daftar Siswa

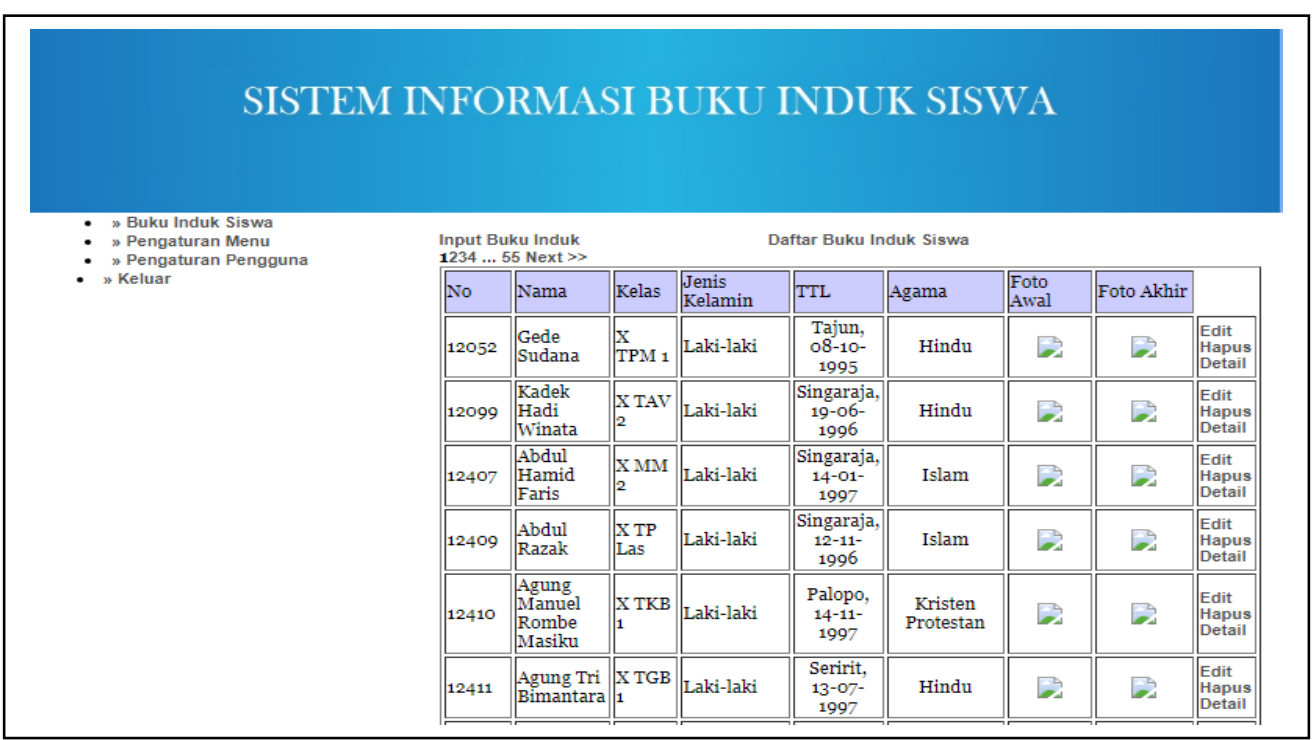

Gambar 9. Hasil Antarmuka Tampilan Halaman Cetak Buku Induk Siswa 
g. Hasil Antarmuka Tampilan Halaman Cetak Buku Induk Siswa

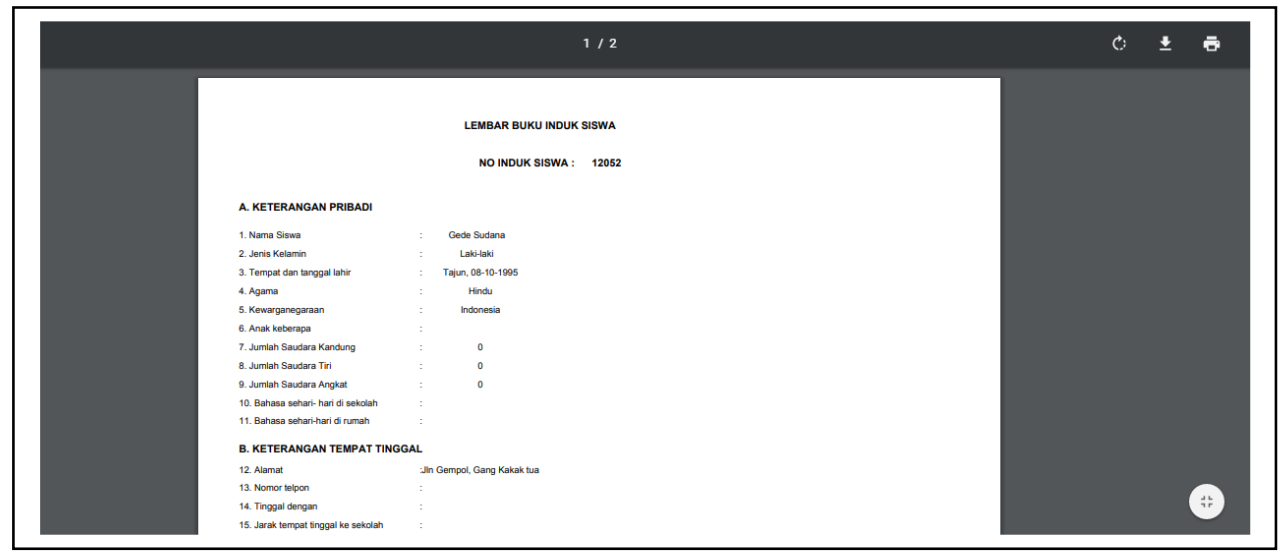

Gambar 10. Hasil Antarmuka Tampilan Cetak Buku Induk Siswa

h. Hasil Pengujian Sistem

Pengujian Perangkat lunak merupakan proses eksekusi suatu program atau sistem dengan maksud menemukan atau, melibatkan setiap kegiatan yang bertujuan untuk mengevaluasi atribut atau kemampuan suatu program atau sistem dan menentukan bahwa itu memenuhi hasil yang dibutuhkan perusahaan[4]. Pengujian perangkat lunak adalah elemen kritis dari jaminan kualitas perangkat lunak dan merepresentasikan kajian pokok dari spesifikasi, desain, dan pengkodean. Sejumlah aturan yang berfungsi sebagai sasaran pengujian pada perangkat lunak adalah [5] :

1) Pengujian adalah proses eksekusi suatu program dengan maksud menemukan kesalahan.

2) Test case yang baik adalah test case yang memiliki probabilitas tinggi untuk menemukan kesalahan yang belum pernah ditemukan sebelumnya.

3) Pengujian yang sukses adalah pengujian yang mengungkap semua kesalahan yang belum pernah ditemukan sebelumnya.

Karakteristik umum dari pengujian perangkat lunak adalah sebagai berikut [5] : Pengujian dimulai pada level modul dan bekerja keluar kearah integrasi pada sistem berbasiskan komputer.

1) Teknik pengujian yang berbeda sesuai dengan poin-poin yang berbeda pada waktunya.

2) Pengujian diadakan oleh software developer dan untuk proyek yang besar oleh group testing yang independent.

3) Testing dan Debugging adalah aktivitas yang berbeda tetapi debugging harus diakomodasikan pada setiap strategi testing

Metode pengujian perangkat lunak ada 3 jenis, yaitu : (1) White Box/Glass Box pengujian operasi; (2) Black Box - untuk menguji sistem; (3) Use case - untuk membuat input dalam perancangan black box dan pengujian statebased. Pengujian perangkat lunak merupakan proses eksekusi suatu program atau sistem dengan maksud menemukan atau melibatkan setiap kegiatan yang bertujuan untuk mengevaluasi atribut atau kemampuan suatu program atau sistem dan menentukan bahwa itu memenuhi hasil yang dibutuhkan perusahaan[5].

Pengujian menggunakan sekumpulan aktifitas validasi, dengan pendekatan black box testing. Menurut Shalahuddin dan black box testing adalah menguji perangkat lunak dari segi spesifikasi fungsional tanpa menguji desain dan kode program[6]. Pengujian 
dimaksudkan untuk mengetahui apakah fungsi-fungsi, masukan, dan keluaran dari perangkat lunak sesuai dengan spesifikasi yang dibutuhkan. Pengujian kotak hitam dilakukan dengan membuat kasus uji yang dengan spesifikasi yang dibutuhkan. Kasus uji yang dibuat untuk melakukan pengujian black box testing harus dibuat dengan kasus benar dan kasus salah. Menurut Pressman, black box testing juga disebut pengujian tingkah laku, memusat pada kebutuhan fungsional perangkat lunak. Teknik pengujian black box memungkinkan memperoleh serangkaian kondisi masukan yang sepenuhnya menggunakan semua persyaratan fungsional untuk suatu program. Beberapa jenis kesalahan yang dapat diidentifikasi adalah fungsi tidak benar atau hilang, kesalahan antar muka, kesalahan pada struktur data (pengaksesan basis data), kesalahan performasi, kesalahan inisialisasi dan akhir program[7].

Pendekatan pengujian Black-Box adalah metode pengujian di mana data tes berasal dari persyaratan fungsional yang ditentukan tanpa memperhatikan struktur program akhir[8]. Hal ini juga disebut data-driven, input atau output didorong, atau persyaratan-based pengujian. Karena hanya fungsi dari modul perangkat lunak yang menjadi perhatian, pengujian Black-Box juga mengacu pada uji fungsional, metode pengujian menekankan pada menjalankan fungsi dan pemeriksaan inputan dan data. Pengujian Black-Box berusaha untuk menemukan kesalahan dalam beberapa kategori, diantaranya: fungsi-fungsi yang salah atau hilang, kesalahan interface, kesalahan dalam struktur data atau akses database eksternal, kesalahan performa, kesalahan inisialisasi dan terminasi. Sejumlah peneliti melakukan penelitian pada pengujian perangkat lunak secara Black-Box. Salah satunya dilakukan oleh Mark Last, Cs pada tahun 2002, Patrick J, Cs, dalam penelitiannya, mereka membahas tentang pengujian reduksi dengan menggunakan input-output perangkat lunak sebagai kategori yang akan dicari kesalahannya dengan metode Black-Box. Dalam proses pengujian perangkat lunak, untuk setiap kasus yang akan diuji harus memiliki identitas dan mempunyai keterhubungan antara sekumpulan inputan dengan output yang diinginkan. Bersifat mencoba semua fungsi dengan memakai perangkat lunak apakah sesuai. Pada tahap ini merupakan tahap pengujian sistem yang dilakukan oleh peneliti menggunakan metode Blackbox Testing. Semua tahap uji coba yang dilakukan dapat dilihat pada keterangan tabel[9].

Pengujian Black-Box berusaha untuk menemukan kesalahan dalam beberapa kategori, diantaranya: fungsi-fungsi yang salah atau hilang, kesalahan interface, kesalahan dalam struktur data atau akses database eksternal, kesalahan performa, kesalahan inisialisasi dan terminasi[10].

Tabel 1. Hasil pengujian sistem informasi

\begin{tabular}{cllc}
\hline No & \multicolumn{1}{c}{ Uji Coba } & \multicolumn{1}{c}{ Uraian } & Keterangan \\
\hline 1 & Akses halaman beranda & Memilih menu beranda & Berhasil \\
2 & Akses halaman login & Memilih menu login & Berhasil \\
3 & Akses halaman administrator & Memilih menu administrator & Berhasil \\
4 & Akses fitur pencarian & Digunakan untuk mencari data siswa & Berhasil \\
5 & Akses halaman input data & Halaman memasukkan data siswa & Berhasil \\
6 Akses halaman daftar siswa & Halaman melihat data siswa & Berhasil \\
7 Akses halaman cetak laporan & Laporan hasil data siswa berupa file & Berhasil \\
\hline
\end{tabular}




\section{SIMPULAN DAN SARAN}

Berdasarkan rancangan dan implementasi pada penelitian sistem informasi buku induk siswa dapat ditarik kesimpulan bahwa dirancang menggunakan Bahasa pemrograman PHP, database MySQL dan framework Bulma. Pengujian dalam penelitian ini menggunakan Black Box Testing. Pengujian blackbox perangkat lunak ini dilakukan untuk menguji seluruh fungsional dari setiap form yang ada dalam sistem informasi buku induk siswa berjalan dengan baik yang dilakukan oleh peneliti oleh sendiri. Pengujian yang telah dilakukan menunjukkan hasil yang baik ditunjukan dengan semua fungsional form berjalan sesuai dengan kebutuhan fungsional yang telah dirancang sebelumnya.

\section{DAFTAR PUSTAKA}

[1] L.P. Cintya Prabandari, "ISMILeSys: Aplikasi Pengolahan Nilai", Jurnal Sains Terapan, Vol. 5, No. 2., 2016.

[2] Tata Sutabri. Analisis Sistem Informasi. Yogyakarta: Andi. 2012

[3] Yakub. Pengantar Sistem Informasi. Yogyakarta: Graha IImu. 2012

[4] Arief. Pemrograman Web Dinamis Menggunakan PHP Dan MySQL. Yogyakarta: Andi. 2016

[5] Rosa AS, M.Shalahudin. Rekayasa Perangkat Lunak Terstruktur Berorientasi Objek. Bandung: Informatika. 2013

[6] AS Ahmar. Panduan Sistem Informasi Akademik Sekolah Berbasis Web. Yogyakarta: Lokomedia. 2012

[7] Roger S. Pressman, Ph.D. Rekayasa Perangkat Lunak (Pendekatan Praktisi) Edisi 7. Yogyakarta:Andi Publisher. 2010

[8] Gede Aditra P., I Made Arisetiawan S., Dewa Gede Hendra Divayana, "Pengembangan Aplikasi Pengendalian Persediaan Obat di Apotek Menggunakan Metode Hybrid Periodic Order Quantity,"Journal of Natural Science and Engineering, vol. 1(3) pp. 120-132.

[9] Febrian, Jack. Pengetahuan Komputer dan Teknologi Informasi. Bandung: Informatika. 2014

[10] Rokhimah Ratnawati, et al. Pembangunan Sistem Informasi Buku Induk Siswa Pada Sekolah Menengah Kejuruan Wikarya Karanganyar.Vol 11 No.3 Tahun 2014 ISSN:1979-9330. 2014 